This is the accepted manuscript of the article, which has been published in Political Geography. 2020, 76, 102093. https://doi.org/10.1016/j.polgeo.2019.102093

\title{
Cartographies of encounters: Understanding conflict transformation through a collaborative exploration of youth spaces in Beirut
}

\begin{abstract}
This paper explores practices and imaginations of space among young people in postwar Beirut. Relying on an innovative collaborative-mapping methodology, it shifts the focus from the traditional analysis of the city at war, centred on anxious urbanism, toward spatial dynamics of conflict transformation. It deploys an ethnographic approach to shed light on everyday perceptions of the urban landscape among a group of students. Their visions of space are composed along conventional tropes, comparable to Bakhtin's notion of chronotopes: images that connect temporal and spatial relationships to describe their ways of inhabiting the city. These images reveal that their experiences of space are not produced exclusively in relation to the memory of wartime topographies and politico-religious territories. Rather, they are also the result of their personal trajectories and agency. For these young people, ordinary encounters inspire a reframing of the political geography of the everyday, including renewed narratives on coexistence and strategies of circumventing the sense of spatial confinement they inherited from the war. The analysis shows that the experiences of these students stand in sharp contrast with the dominant image of unbending intergroup boundaries in postwar Lebanon. Young people's abilities to navigate, negotiate and rediscover social encounters in a complex, changing environment call attention to the transformative power of micro-situations in postwar contexts. Through highlighting their original lifestyles and ways of thinking, this paper argues that the city, far from only symbolizing and reproducing conflicts, is also the place where mundane practices and imaginations reinvent the social fabric.
\end{abstract}

Keywords: Youth; Time-space; Conflict transformation; Collaborative ethnography; Encounters; Lebanon.

\section{INTRODUCTION}

"Cities, warfare, and organized political violence have always been mutual constructions" (Graham, 2004, p. 1). This intimate relationship has been the focus of a great number of academic works, typically investigating the destructive power of armed violence over urban environments and the transformation of city architecture in times of conflict, with skyscrapers turned into sniper lairs (e.g., Ristic, 2014, p. 342), (air)ports becoming hubs for choreographies of a war economy (e.g., Endres, 2003, p. 131) or hotels converted into strategic infrastructures (e.g., Fregonese \& Ramadan, 2015, p. 801). More recently, in the wake of the 9/11 events and the subsequent attacks in European cities, another considerable body of literature has emerged, concentrating on the urban alterations imposed in the name of control and securitisation of a city. Studies of "military urbanism" (Graham, 2012), visible in spaces like London's “Ring of Steel” (Coaffee, 2004), and advances in 
technological surveillance (e.g., McCahill, 2002) have contributed to the rise of "anxious urbanism" (Farish, 2004; Williams, 2004), nourished by the conviction of living in an era when "a general desolation has transposed many bizarre racial, religious and linguistic enmities into scenarios of unrelieved urban terror" (Appadurai, 1996, p. 153).

However, as Mona Harb (2017) notes, this research stream has predominantly considered cities from the global North, while under-examining people's everyday experiences with these spatial dynamics of urban "protectionism" (Beck, 1999, p. 153). This "everyday" of human experiences has to be understood here as "a place, not spatially or temporally circumscribed, but imperfectly delineated by the individuals who people it", which works as a way into the exploration of other social processes (Fox \& Jones, 2013, p. 396). Focusing on the everyday exposes another relative blind spot: beyond the well-documented issue of the reconstruction of urban infrastructure, the topic of post-conflict evolutions in city landscapes has received surprisingly little attention. If, "being chiefly human, cities can be killed" (Spiller, 2000, p. 6), then can they be resurrected? Conflict transformation literature (e.g., Lederach, 1995; Miall, 2004) has highlighted how social conflict is part of human interactions and has to be understood as a transformative dynamics with the potential to "move in destructive or constructive directions" (Lederach, 1995, p. 19). From that perspective, comprehending processes of transformation from unpeaceful to peaceful relationships (or vice versa) in the context of urban spaces necessitates more than addressing the geopolitics of war. It also requires consideration of the relational, face-to-face human interactions that contribute to the evolution of societies and the alteration of the city. It is all the more relevant in the contexts of internal wars, characterised by a state of fragmented sovereignty - i.e., "an exception to the rule of indivisible exercise of power over national territory" (Su, 2018, p. 23). In such circumstances, given the state's incapacity to impose its political authority, defined both in terms of monopoly of legitimate violence and control over a geographical territory (Agnew, 2005, p. 443) because of internal disputes (e.g., Brubaker, 2004; Kauffman, 2001) and/or external interventions (e.g., Risse, 2011), the lack of central power cultivates distrust and violence between groups (Bakke et al., 2018, p. 160). Constructive post-conflict transformation thus implies not only agreement between the warring factions but also the return of everyday practices that facilitate weaving the social fabric back together. Urban environments play a crucial role in that respect, as the place where people live and the social composition of the neighbourhoods in which they interact deeply affect their attitudes (e.g., Sharkey \& Faber, 2014). Hence, looking into the everyday of urban practices enables investigation of the social phenomena at work in the processes of conflict transformation.

The case of Beirut provides fertile ground to undertake this endeavour. Between 1975 and 1990, a succession of brutal internal wars devastated Lebanon and its capital. Commonly described 
as sectarian conflicts, these violent episodes intertwined political, social and economic factors playing at local, regional and international levels (Picard, 2002; Traboulsi, 2007). Rather than being a manifestation of backward, ever-lasting social divisions, the sectarian discourses and practices originate in an essentially modern cultural production born in the second half of the nineteenth century (Makdisi, 2000). Materialised in the institutionalisation of religious categories in the political and legal orders established during the late Ottoman period (1861-1915), and reinforced during the French Mandate (1920-1943), this "culture of sectarianism" (ibid.) offered powerful ideological tools to redefine identity narratives and transform social hierarchies, emphasising the importance of religious belonging. In 1975, the collapse of the inter-elite consensus precipitated the country falling into a spiral of violence. Beirut in particular underwent what was later, in another context, described as "urbicide" (Warchitecture, 1993), a "widespread, intentional destruction of the urban environment" (Coward, 2004, p. 157). Despite aiming to annihilate inter-sectarian life - "the living together" ( 'aysh al-mushtarak), particularly in the cosmopolitan city centre - violence failed to destroy all forms of solidarity (e.g., Beydoun, 1993; Hanf, 2015), but it did durably shape both the urban landscape and social interactions. It divided Beirut along the "Green Line", the frontline separating what was referred to as "the West", mostly populated by Muslims, and "the East", predominantly Christian. Within each zone, a multitude of militias and armed groups were fighting for control over neighbourhoods. The end of hostilities did not stop this process of fragmentation of sovereignty. On the contrary, a state-sponsored system of amnesia, manifested in the 1991 amnesty law, allowed political and sectarian memories to thrive (Haugbolle, 2010; Volk, 2010). While the postwar maintenance of socio-political territories (e.g., Deeb, 2006; Harb, 2010) and the politics of reconstruction (e.g., Humphreys, 2015; Leenders, 2012) - as well as the ways these two processes intersect - are well-documented, far less is known of the social dynamics of recovery and conflict transformation arising among Beirut's dwellers almost 30 years after the end of the internal wars. 1 In this article, I suggest that an interpretative ethnography approach provides an adequate tool to move beyond the conventional, largely monolithic understandings of postwar Lebanon. Because it is "both empirical research and a form of critical theoretical practice" (Malkki, 2007, p. 166), interpretative ethnography allows us to develop renewed knowledge of how Beirut's urban space is experienced today, at the same time embedded in local realities and highlighting the agency of specific groups of people. Recent works focusing, respectively, on Beirut (Fawaz et al., 2012) and the Middle East (Fuccaro, 2016) precisely encourage us to shift the focus towards micro-level

\footnotetext{
1 The 1975-1990 wars were not the last episodes of large-scale violence in Beirut. In 2006, the Israeli army bombed the southern suburb of Beirut, known as a Hezbollah stronghold, destroying entire neighbourhoods and killing 1,183 civilians (Mermier \& Picard, 2007, p. 5).
} 
observations of the everyday to understand how personal experiences of violence, memory and encounters shape the physical and symbolic spaces of a city in postwar contexts.

This article proposes to contribute to this task by empirically exploring youthful practices and representations of space in Beirut. It asks how young people experience and reflect on spatial fragmentation in their everyday environment. How powerfully do wartime memories remain embedded within their urban framework? To what extent do their contemporary spatial experiences evoke dynamics of conflict transformation? To answer these questions, this paper draws on interviews elicited from collaborative maps developed with Lebanese students. My intention is to use their stories as a starting point to document everyday practices and imaginations of the city, and to contribute to a refined understanding of mundane experiences of conflict transformation in a postwar society.

\section{MAPPING YOUNG PEOPLE'S LIVED SPACES COLLABORATIVELY}

Before presenting how the stories I collected illuminate relations to space in postwar Lebanon, I deem it important to outline my approach. This article draws on collaborative interviews - i.e., following an interview practice that "deliberately and explicitly emphasizes collaboration [...]" (Lassiter, 2005, p. 15, emphasis in original) - realised with students of the American University of Beirut (AUB) in the district of Hamra.2 Starting from Henri Lefebvre's (1991, p. 33) notion of lived space, which defines space as both physically experienced (real space) and mentally invested with symbolism and meaning (imagined space), I conceived collaborative map-elicited interviews to investigate both the materiality and the imagination of space among young people raised after the wars ended. Participants, recruited with the assistance of AUB faculty members, were willing to take part in a face-to-face interview. At the beginning of the conversation, I asked them to look at three maps - their campus, the city of Beirut and Lebanon - and mark places that carry special meaning in their life.3 From their maps, we discussed the meaning of their selections in order to locate their spatial routines and practices (their real space) as well as the imagination and memory embedded in these frameworks (their imagined space). Using this collaborative technique, I gathered 13 in-depth interviews, complemented with ethnographic material gathered during

\footnotetext{
2 Fieldwork took place in April 2016 as part of a CEDRE research programme funded by Campus France (no. 32939WE). 3 This design was created with an exploratory intention. While the main scale of inquiry was the city, I added the campus in order to grasp students' concrete daily practices. It proved to be a valuable addition, as many ways of inhabiting the campus and the city were comparable and complementary. In contrast, the maps of Lebanon generated more general, less detailed discussions, as if this larger scale was somehow depersonalised or uninhabited. Therefore, the results were less significant for the purpose of this paper. This outcome emphasises the embodied and situational dimension of spatial experiences.
} 
previous fieldwork in universities and student milieus.4 Aged between 21 and 27, with the exception of a 34-year-old, the participants were mostly women (nine), and they studied at either the Department of Architecture and Design or the Department of Sociology.5 They all came from and lived in various areas around the city: three re resident in the southern suburb, known as a Hezbollah stronghold; four were resident in West Beirut (including one living on campus, as her family lives in South Lebanon); three in East Beirut, among its mostly Christian-populated suburbs; two in the Christian town of Jounieh, some 20 kilometres north of Beirut; and one in Baabda, a suburb overlooking the capital.

The choice of working with AUB students, whose profiles are in many ways not comparable with the rest of Beirut's youth, is grounded in the ethnographic methodology that underpins this research. At the practical level - research being, after all, a practical activity (Garfinkel, 1967) AUB offered several advantages. As well as being the oldest university and among the biggest in Beirut, it comprises a unique campus (in contrast to the public Lebanese University, for instance), thus facilitating investigation, and, as we will see, it maintains a form of symbiosis with its neighbourhood. Even more crucially, I had already amassed a great amount of ethnographic material on AUB and its students (e.g., Author, 2013) to complete the collaborative interviews. Addressing my research question from the point of view of a limited number of students, mostly belonging to the social elite, 6 stands in sharp contrast with the dominant conventions in political and social sciences, still subjugated by the imaginary of natural science. However, this "situatedness" of the study, as well as being consubstantial with knowledge production in fields like social anthropology and ethnography, is actually the main strength of this tradition of research (Malkki, 2007, p. 166). Contrary to quantitative studies that "leave relatively invisible the situatedness and partialness of the results" (ibid., p. 170), ethnographic methods develop theoretical insights that critically take into account the complexity and limitations of local contexts (Cerwonka, 2007, p. 15). Accordingly, the "particular truths" (Leach, 1967, p. 78) explored in this article cannot be representative of the Lebanese youth as a whole. They are highly empirical, context-specific "situated knowledges", the product of embodied, located experiences (Haraway, 1991). As such, it is not their purpose to depict a holistic understanding of the condition of the youth in postwar

\footnotetext{
4 The fieldwork took place during successive projects from 2004 to 2016 . The length of these trips varied greatly, from weeks to full academic years.

5 Their religious affiliations were diverse (four Christians, four Shi'ites and five Sunnis), as was the extent of their religious practice. Because the dynamics observed were comparable for all religious profiles, I made the choice to avoid assignation and mention sectarian affiliations only when it contributed to the understanding of our conversations. 6 The AUB is clearly an elite institution. Tuition fees average around 15,000 USD a year. However, four of the 13 participants were receiving full scholarships, covering the totality of their tuition. Therefore, not all participants belonged to upper-class families.
} 
Lebanon - such an endeavor is unattainable, whatever the method. Rather, I am concerned with the process of "understanding", as Gadamer (1999) calls it, the social practices and discourses of a specific youth. This method, because it grasps the complexities and contradictions beyond the surface, turns out to be particularly relevant in uncovering social changes and cultural negotiations at work in the process of conflict transformation.

Following this approach, I use my dialogues with this particular group of students "as a strategy through which broader social forces, properties, and processes can be understood as constituted in practice" (Fine \& Fields, 2008, p. 31). These conversations are more than seemingly insignificant anecdotes. As Asef Bayat (2010) has demonstrated, daily acts have actively contributed to the transformations of societies in the Middle East and beyond. I analyse the interviews using an interpretative approach inspired by Mikhail Bakhtin's idea of "chronotopes" (Bakhtin, 1981, p. 84). According to Bakhtin, chronotopes represent "the intrinsic connectedness of temporal and spatial relationships". They work as images or "monuments" that organise the narration of identity in its relation to time and space. As with Bakhtin's identification of classic "time-spaces" that sustain the narrative construction of genres in Russian novels, I noticed patterns in how the drawing of the maps and the narratives they elicited sketched specific articulations of time and space. Five images systematically surfaced: circles representing familiar places and the routes connecting them; crossings symbolising separations between different urban milieus; gates or other entry points to specific territories; and places they identified as emblematic of youth sociability. These five patterns were mobilised to construct stories embedded in specific locations and temporalities. The notion of chronotope thus imposed itself as the perfect tool to understand this synergy between time and space. From there, "tacking back and forth" (Malkki, 2007, p. 183) between Bakhtin's and Lefebvre's theories on the one hand and the collaborative interviews as well as my ethnographic knowledge of the context on the other, I progressively forged new chronotopes through "a dialectic of guessing and validation" (Ricoeur, 1973). I believe they convey the experiences of space articulated by these young people, whose stories performed ways of occupying (real space), imagining (imagined space) and appropriating (lived space) urban spaces.7 Familiar areas referred to practices of $d$ welling; routes referred to experiences of navigating the city; crossroads referred to positioning strategies in interactions; gates referred to transitioning between worlds; and youthful sites referred to discovering new spaces. These five ways of practising Beirut intertwine in the stories and compose coexisting modes of delineating the bonds and boundaries between identity and alterity in the Lebanese capital. Analytically, I organise them into two sub-

7 I am grateful to one reviewer of the original manuscript for suggesting this formulation. 
groups (one couple and one trio), in which dynamics of time and space intersect. The first cluster is composed of the two interdependent notions of dwelling and navigating, which picture the continuous appropriation of the urban space during the life course. The second relates to modes of encountering alterity in the city. It exposes a symbolic progression from meeting with alterity in daily interaction (positioning), to transitioning between social worlds and, finally, discovering alternative understandings of bonds and boundaries in the city. Using these experiences as conceptual tools to read the tales voiced during the interviews, I argue that the visions of space and encounters I collected are not produced only in relation to the memory of wartime topographies and politico-religious territories. Rather, they are also the result of intimate and embodied modes of experiencing landscapes rooted in people's life trajectories and perceptions of their own position within their society. Remarkably, some of these experiences foster a reframing of the political geography of the everyday and renewed narratives on coexistence.

\section{FAMILIAR SPACES AND BEYOND}

The first sub-group of chronotopes evokes the familiar spaces that spontaneously arose from the collaborative maps. They describe intimate places and moments in the lives of the participants, as well as their spatial and diachronic expansions as their own life trajectories unfold.

\section{Dwelling: Time-Spaces of Intimacy}

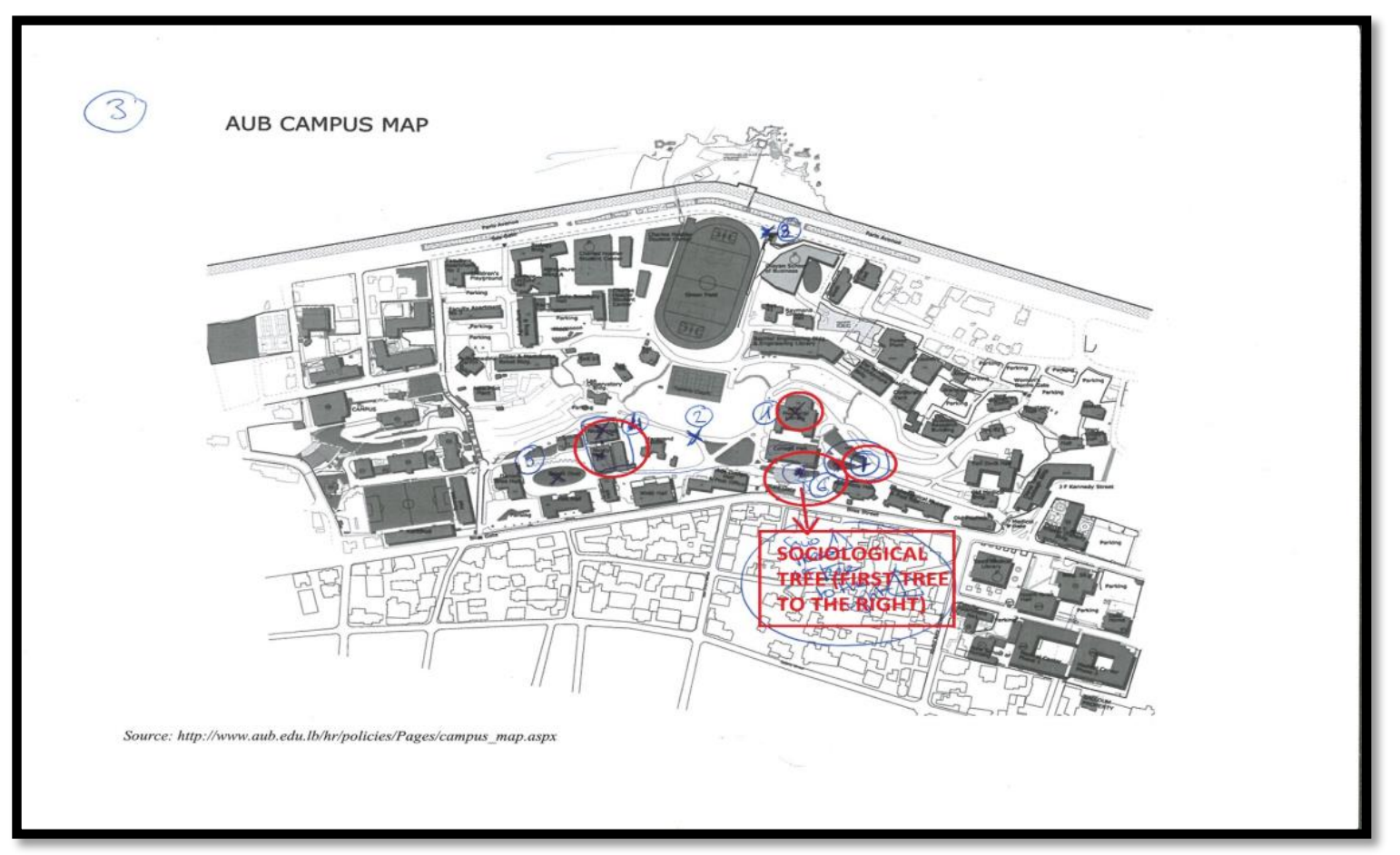

Figure 1. Dwelling in Kamal's collaborative map of the AUB. 
The first trope emerging from the maps is materialised by the circling of delimited areas, depicted as domestic or familiar spaces. At the scale of the university, it takes the form of specific zones on the campus where daily activities unfold: departments, smoking areas, cafeterias, sport facilities, etc. Students include all these places in their lived space. The AUB campus present itself as an island of 250,000 square metres in the heart of the capital, surrounded by walls that mark the separation between the university and the rest of the urban fabric. Within the enclosure, the topography divides the space between a lower campus, close to the corniche on the littoral, and an upper campus, accessible from the city and the district of Hamra. Steep stairs and alleys circulate the campus, connecting both parts together. Studying on one side or the other plays a crucial role in the experience of the university space. It largely influences the ways students enter and exit the university, as well as which cafeteria they use and the kind of sociability they encounter. The lower campus grouping has fewer faculties and appears to be more specialised, which enables the students to appropriate daily spaces and create disciplinary-inspired cliques:

I highlighted first the space around our department. The smoking area is where we spend most of our time. We have room to build our models and all sorts of things we have to do [as architecture students]. All our classmates are there (...). The rest of the campus is more alien to me. (...) I don't spend much time there. [Nisrine, 8 undergraduate student, West Beirut]

In contrast students have a tendency to depict the upper campus as a more anonymous space, whether they study there or not, and it is also more often used for gatherings as well social and political activities. This differentiated use of space explains that the two sides of the AUB relate to distinctive imaginaries. While it also hosts the library and thus attracts many students, the upper campus is often presented as more central in terms of student sociability and hence more affected by mutual observation and attention-seeking practices. For example, students have nicknamed a nodal point in the upper campus landscape "the zoo", reflecting its theatrical dimension and the importance of being seen in campus interactions. Students' stories often highlight such landmarks, which seem to play a great role in recollecting key moments in young people's time at the AUB:

After one of our [sociology] courses, one of our classmates found herself overwhelmed, feeling sad because of a professor's comment. (...) We found her crying, sitting by this tree [pinpointed on the campus map]. We joined her and it became a routine. After the class, we would gather around the tree. (...) So we labelled it the "sociological tree", it's our tree. [Kamal, master student, Baabda]

The memory of the "sociological tree" composes a nostalgic longing for an idealised university life dominated by friendship and peer-group solidarity. Such accounts reveal the importance of

\footnotetext{
${ }^{8}$ All names and explicitly identifying details have been changed.
} 
inhabiting intimate spaces, in which relations to the other is dominated by familiarity, relief and well-being. A similar trope exists at the level of the city:

Most of the places [on his map of Beirut] are related to when I was young - for instance, the Sanayeh garden. It is a very old park in the city. My father used to bring us there every now and then. And as you know, there are not many green spaces in Beirut, so it was like an amusement park for us. It's a memory I hold on to. [Rami, master student, southern suburb]

Dwelling is the time-space of daily activities, populated by familiar characters and significant others, parents, siblings, friends or colleagues. As places of emotional investment, they convey the view of an entre-soi and, to a certain extent, closure rather than openness. The participants were fully aware of this bounded dimension. For example, Luna explains that she lives with her parents in the Keserwan district, near the coastal city of Jounieh, often presented as part of the heartland of Christian Lebanon. She describes her region as "a bubble", in which people tend to feel safer:

Now, they have even put a road sign to mark the entrance into Keserwan. It reinforces the impression of a tribe or community. [Luna, undergraduate student, Jounieh]

The time-space of dwelling hence highlights the notion of bounded territories informed by the memory of violence and the imaginary of sectarianism. Nonetheless, while it often relates to bounded locations and nostalgic projections, spaces of intimacy are not static entities, nor are they systematically past-orientated. They expand in parallel with the deployment of life spheres. Intimate zones evolve with time, as the life trajectory of the actors open up new spaces.

\section{Navigating: Time-Spaces of Itinerancy}

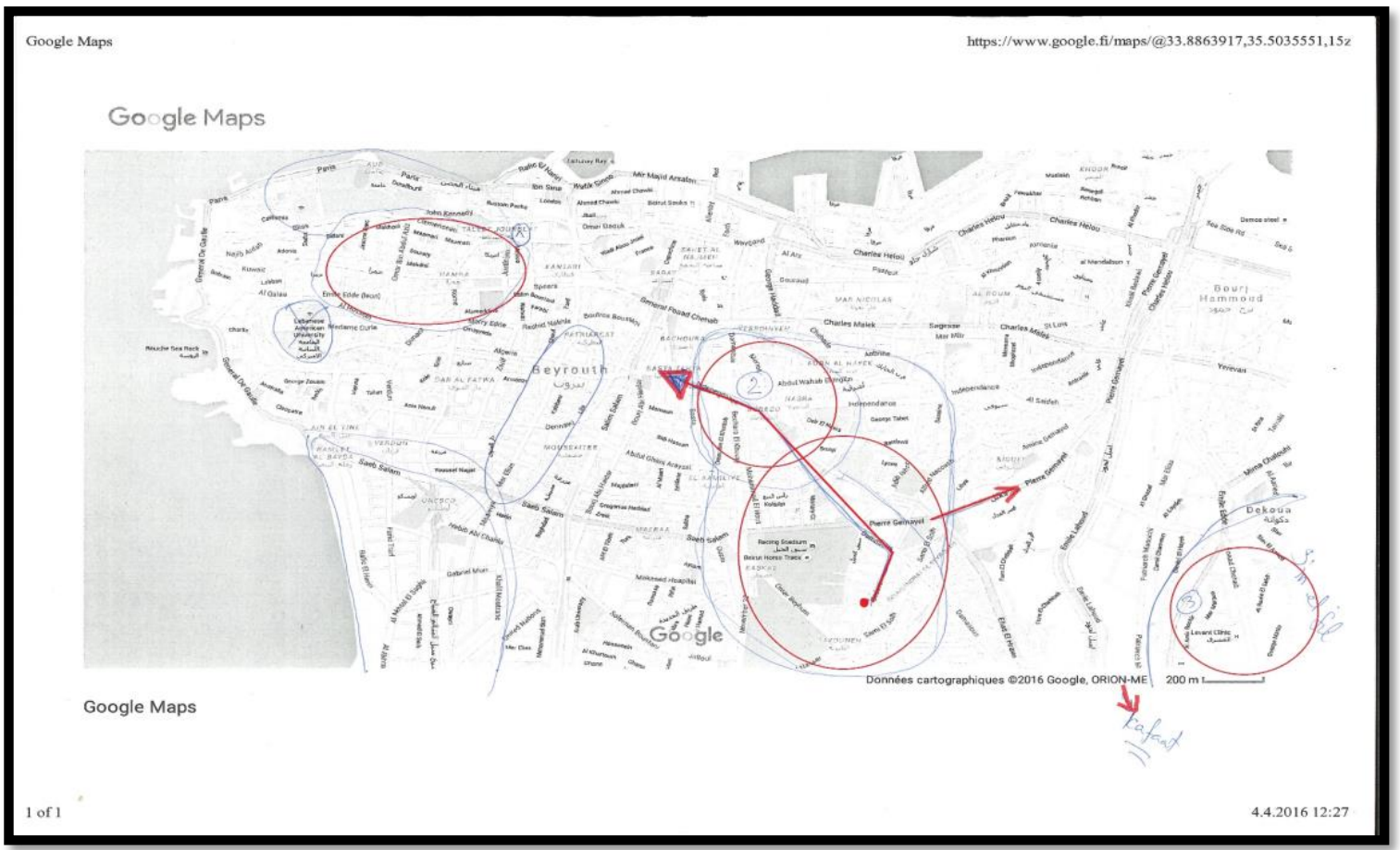


Figure 2. Navigation in Maya's collaborative map of Beirut.

Drawing roads stands out as the second immediately observable feature on collaborative maps. Students drew all sorts of routes to describe their daily commute to the university and back, explain their explorations of Beirut's neighbourhoods, or even narrate their routines within the campus. These roads bond familiar spaces that would otherwise remain disconnected entities. As such, they highlight the core of students' lived space:

My space is first where my family is, the district of Badaro and Furn al-Chebbak. That's where I was first introduced to Beirut [after moving from Nigeria where she was born]. (...) Then I went to AUB and my space became Badaro and Hamra. And now, I have added Sin el-Fil [in the eastern suburb] for work. (...) I negotiate between these three spaces: work, family and studies. [Maya, master student, East Beirut]

In her words, Maya puts forward the notion of navigation, a useful concept highlighting the ways "people make sense of and work their way through diverse urban environments, often in contexts of deep political, economic and social inequality" (McFarlane \& Anjaria, 2013, pp. 5-6). This notion is particularly relevant in the Lebanese context, fragmented in a juxtaposition of territories physically identified by sectarian and political signs. On the streets of Beirut, flags, graffiti and posters fill the space with ideologies, symbolically prolonging the physical divisions that characterised the city during the war (Haugbolle, 2010, p. 161). The districts of the Lebanese capital remain subjected to powerful identity claims, and young Beirut dwellers born in the postwar era must, in their daily activities, "get along in a network of already established forces and representations" (De Certeau, 1984, p. 18):

When you say Dahiyeh [the southern suburb], you know what religion it is [associated with Shi'ites and Hezbollah]. (...) And when I say that I am from Keserwan [a region north of Beirut, mostly populated by Christian Maronites], people have an idea as well. [Luna]

I grew up in East Beirut and started my studies at the Jesuit University on Damascus Road [the former Green line]. For five years during my stay there, I had never crossed to the other side of the street! [Clara, master student, East Beirut]

But navigation is not only a question of representation. It also relates to concrete problems that students must solve on an everyday basis. In particular, Beirut is afflicted by massive traffic congestion, making daily commutes complicated. The fact that participants systematically noted their everyday itineraries reveals the significance of this problem in their experience of space. These difficulties intersect with the persistence of violence in the Lebanese capital (in particular, the threat 
of car bombs and suicide attacks9) and the responses it generates, such as roadblocks or security checkpoints:

I am commuting everyday [between the AUB and his neighbourhood of Burj al-Brajneh in the southern suburb]. (...) You have traffic jams most of the time. (...) You have to learn where the checkpoints are at the entrance of the suburb, (...) which are run by the police, the army or Hezbollah security. (...) If you go through secondary checkpoints, it's easier. (...) You adapt in front of every problem. [Rami]

A study by Mona Fawaz, Mona Harb and Ahmad Gharbieh (2012) has similarly highlighted how security mechanisms generate strategies of adaptation from the city's dwellers. Residents employ schemes to navigate and negotiate between security apparatuses that close off entire parts of the capital, as well as dealing with spatial identity assignations in complex political and sectarian environments, and urban disorder (absence of de facto public transportation, detours imposed by construction work and real-estate fever, pollution, etc.). Reflecting on her triangulation between the three areas constituting her main life spheres, Maya explains:

I always have to negotiate between my apartment, my family house, and my work to navigate the city better. Traffic makes me negotiate space. I choose where to stay and how to move between these three spaces based on traffic. (...) I usually spend the weekend at my family house and stay at my apartment during the week, but if I have to work in Sin elFil, then I would probably go back to the family house, it makes it much easier to reach my work place. [Maya]

Making their way between different spheres of everyday life - such as, in this case, family, studies and employment - necessitates constant negotiation, which goes beyond logistic issues. Very few young people rent an apartment. Unless distance makes it impossible, the majority continue to live at the family house during their studies. This is due to both material (rents are expensive and considered an unnecessary burden alongside costly university education) and social motives. It is often still considered inappropriate for unmarried youths to live outside the family, especially women:

It was difficult to convince my parents [to have my own flat]. But I work as a fundraiser at the AUB to cover my rent. (...) Myself, I have no problem with living alone. (...) It took me a year to do it. (...) I have always dreamed of the AUB, but after high school, I preferred, at first, the safe solution of the Jesuit University close by, as I didn't know how to navigate. [Clara]

Drawing and narrating itineraries demonstrates how young participants navigate the city, spatially and diachronically. It shows their movements, driven by concerns of efficiency and security. However, it also works as a metaphor for young people's life trajectories with the invention of their own space, separated from their family, and the changes in their understanding of the world that

\footnotetext{
9 In the wake of the Syrian Civil War, Beirut, and particularly its southern suburb, was the target of jihadi attacks between
} August 2013 and November 2015, killing more than 100 people in total. 
might come with it. Therefore, the time-space of these navigation practices is an interim moment, between the familiar and the alien. Roads drawn on collaborative maps attest to the active search for pathways in an environment hampered by physical and symbolic immobilism. They highlight inventive solutions to practical constraints, as well as young people's efforts to move forward in their lives and, in doing so, necessarily face the stereotypes and representations anchored in space. As such, navigation captures the struggles of living in physically, politically and socially fragmented settings, illuminating practices that open up potential avenues of agency.

Together, dwelling and navigating delineate the familiar spaces of the participants, organised in reference to intimate hubs and the networks that connect them. But the interdependence between these two ways of living in the city goes beyond their formal bond. As more routes are explored, both materially and symbolically, during the life course, familiar spaces expand and the ways of inhabiting them are transformed. As the familiar spaces shift with the imperatives of studies or employment from the original family house towards new areas, more routes are traced and the potentiality of an encounter with alterity increases. Far from being fixed, the interaction between navigation and dwelling is therefore renovated through time.

\section{TIME-SPACES OF ENCOUNTER}

While the first sub-group of chronotopes mainly focuses on familiar spaces and comfort zones (although sometimes challenged), and therefore appears to narrate processes of self-identification with and within the city, the second engages more directly with the dynamics of social encounters in the urban landscape. For the participants, the following three ways of experiencing Beirut are characterised by the complexification of their relation to their surroundings, as the dichotomy between identity and alterity, insiders and outsiders becomes increasingly blurred. 


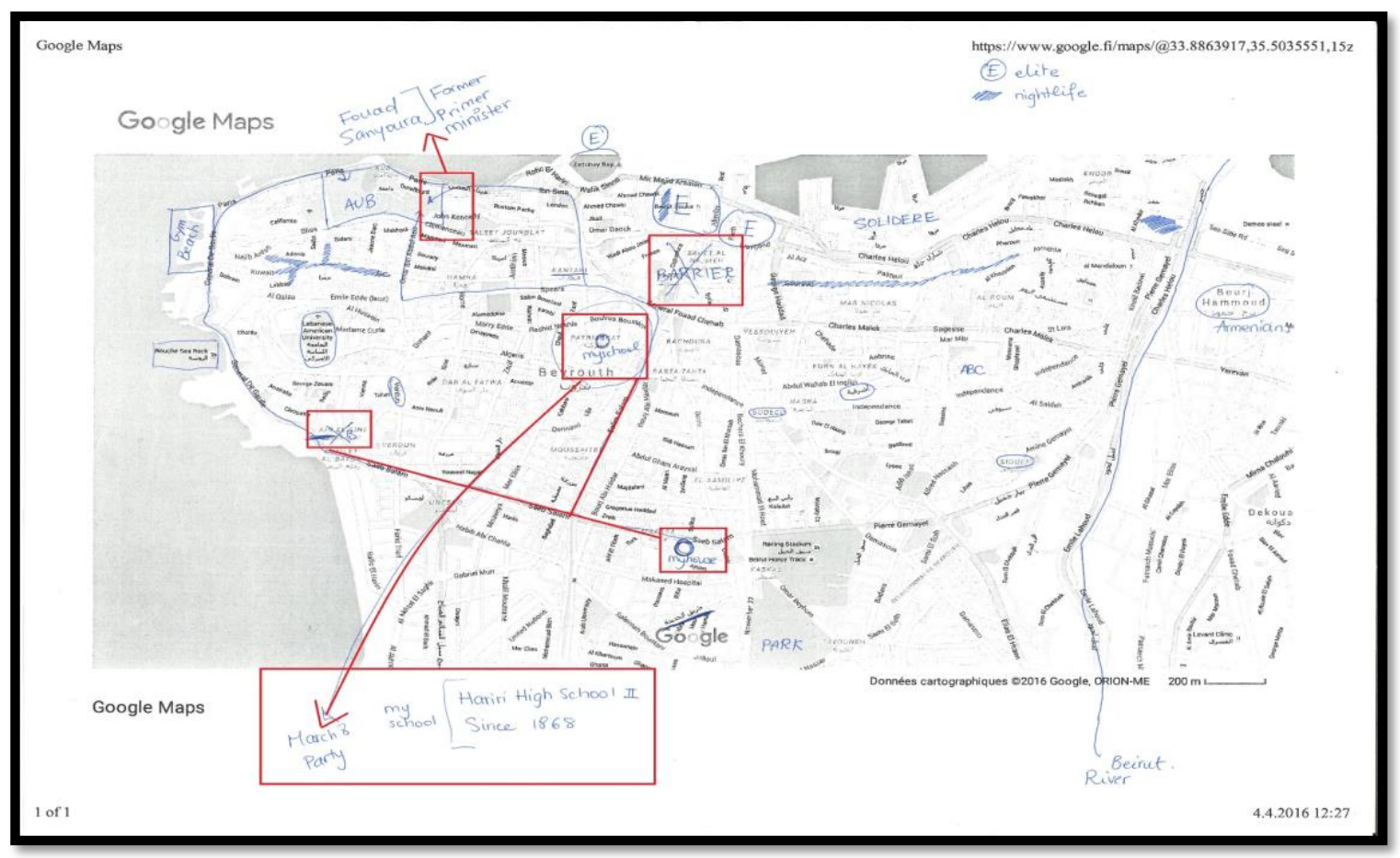

Figure 3. Positioning in Hoda's collaborative map of Beirut.

Both navigating and dwelling outline familiar and alien territories that remain underexplored. The presence of these grey areas is often initially dismissed in the conversation, vaguely designated by formulas like "I never go there" or "I don't know this zone." Yet, as the conversation unfolds, more complex images surface. References to crossroads or nodal points denote the significance of positioning in the experience of the city. They depict participants' understanding of past and contemporary divides between regions or neighbourhoods, each being routinely identified with a dominant political force and a majoritarian sectarian group:

I don't like my neighbourhood because problems always break out there. (...) For instance, the street fighting of May 2008. (...) My school was also politically identified with one party [the Future Movement of the Sunni leader Saad Hariri] but it is located in a district affiliated with a rival group [the Amal Movement, a party recruiting among Shi'ites and opposed to the Future Movement]. (...) There were always troubles between young men from the neighbourhood and some of my schoolmates. [Hoda, undergraduate student, West Beirut]

The capture of space in terms of territories locates the distinction between insiders and outsiders at the heart of spatialised interactions. Newcomers are particularly subjected to this distinction. Nina, a fourth-year student in Architecture born and raised in the Lebanese diaspora in Brazil, explains how she felt when moving alone to Beirut to start her studies at the AUB four years ago:

I had to adapt to people with different backgrounds. I had to learn the places I could go or not, what kind of clothes I could wear and what I could not. (...) I have been learning the 
hard way. (...) When I first arrived, I was totally shocked. (...) I found an apartment in Mar Elias [a central, popular neighbourhood of the capital, politically dominated by the Amal Movement]. It was a very closed neighbourhood. (...) With young men guarding the entrance halls of the buildings, holding political flags [of Amal]. (...) With all the people looking at you. (...) They know you are not from here. [Nina, undergraduate student, West Beirut]

The physical space of her first neighbourhood as well as its strong identification in terms of gender, partisan affiliation and sectarian belonging generated a sense of alienation that she could not overcome, particularly as she has not mastered the Arabic language. She recalls having learned how to negotiate her presence to fit as well as she could in this environment. After one year, she moved to another part of the city, closer to the university, where she feels "less different" due to, as she puts it, a lower density in the urban landscape and a greater diversity in the population. She confesses that she still avoids her former neighbourhood. Her experience of exclusion also came with the discovery of daily manifestations of sectarianism, which she initially encountered with astonishment and disbelief (ibid.). According to Nina, daily interactions among the Lebanese in Brazil are not so strongly dictated by sectarian affiliations. Although such a claim is difficult to document or confirm, it is common among young people from the diaspora. Many explained that while they were well aware of their religion, being Christian or Muslim, they actually only discovered their precise sectarian belonging after moving to Lebanon: "In Brazil, no one cares about other people's religion. So when I came here, I didn't even know my religion (...)" (AUB student, quoted in Author, 2013, p. 168). While Nina seemed somewhat lost in transitioning from one world to another, other students hold more resources to negotiate their presence in specific territories. For instance, Clara explains how she was finally able to be accepted in Hamra's secular and gentrified milieus:

My family originates from Corniche al-Mazraa in Beirut. (...) I only went there two or three times in my whole life. (...) But there are not many people who actually originate from the city. Sentimentally, I'm very attached to Beirut. So I like to brag a little bit about it (...). That way, I can justify my attachment to the city with roots. [Clara]

Clara's account allows two observations. First, territories are not defined exclusively in terms of sectarian identities. The district of Hamra is, for instance, closely connected with a secular, leftist ideology. Originating from the 1950s and 1960s, when the neighbourhood was a hotbed of Arab socialism, this association still resurfaces in the interviews. Accordingly, it is more accurate to describe these lived territories as incarnations - or even allegories - of subcultures or sub-societies coexisting in contemporary Lebanon. Some of these sub-societies are articulated in terms of sectarian affiliation, such as the so-called hala islamiyya or Islamic sphere existing in Hezbollahdominated areas (e.g., Deeb, 2006; Harb, 2010). Yet, this is not always the case, as the example of 
Hamra illustrates. Present-day political organisations play a pivotal role in the perpetuation of spatial identification and, more globally, the maintenance of alternative universes of signification, and because of that, they have been convincingly conceptualised as partisan societies (Mermier \& Mervin, 2012, p. 24; Author, 2013, pp. 30-31). Beirut's spaces are not essentially sectarian but, as Henri Lefebvre notes, "political and ideological" (Lefebvre, 1991, p. 31). The second noteworthy comment is that family origins remain crucial symbolic capital in negotiating the status of insiders. It confirms the power of references to localism and kinship in social interactions.

These experiences of the city correspond to time-spaces in which boundaries and cleavages are underlined. They highlight processes of identification and positioning, understood as the dynamic and relational identification in social interaction (Davies \& Harré, 1990, p. 44). Students use various resources to negotiate their positions as insiders or outsiders, endorsing the fact that identities are not defined by essence but rather by boundary perception and differentiation (Hall, 1990, p. 223). Distinctions between identities actually surface from reciprocal positioning, supported by narrative constructions composed to make sense of these relationships. The consequence is that, as Paul Ricoeur (1990) claims, identity and alterity are intrinsically intertwined. Ultimately, positioning encapsulates the moment and locus of social encounters, in which ideas - as well as ideals - of the self and the other are jointly constructed.

\section{Transitioning: Time-Spaces of Vacillation}

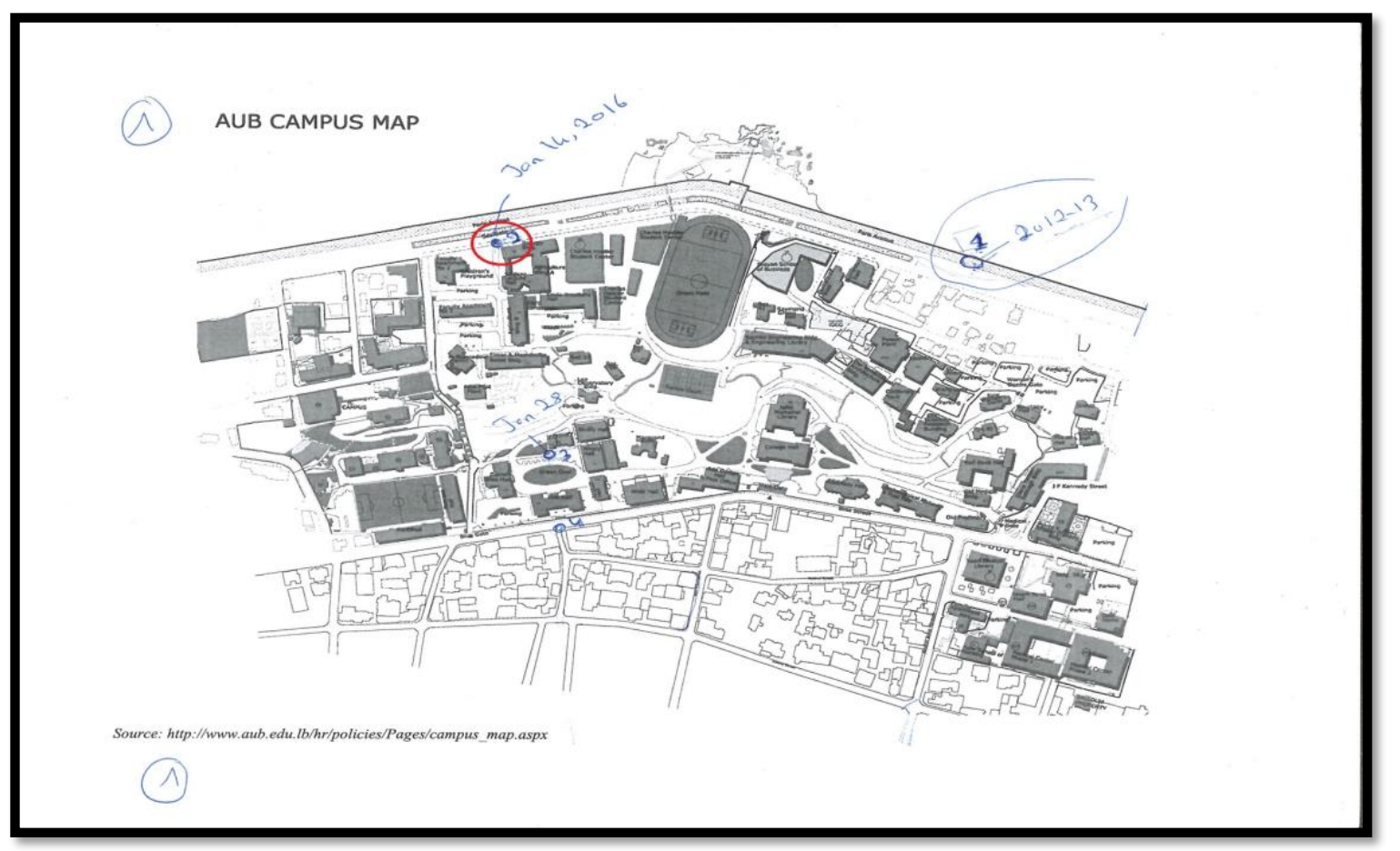

Figure 4. Spaces of transition in Gloria's collaborative map of the AUB. 
The capacity to negotiate space and be recognised as an insider within a territory points towards another way of living in urban surroundings: moments and spaces of transition from one world to another. When presented with the map of the AUB and its neighbourhood, participants systematically represented the gates they use to enter the campus. Practically, these gates are important reference points in their daily routines, milestones of transition between their various life spheres. The relevance of transitioning between the inside and the outside is all the more acute, since interviews depicted the AUB as a world of its own. Reflecting on the interrelation between university campuses and the city in Beirut, Michael Davie (1998, p. 4) argues that the AUB has constructed a paradoxical relationship with its urban surrounding. Historically, the university has been physically separated from the city while also in intellectual symbiosis with the leftist and cosmopolitan lifestyle prevailing in Hamra. Therefore, the image of the gates bears both material and symbolic meanings. Entering the university signifies access to its population. As such, the AUB plays a role of intermediation between students from diverse horizons. Because of its standing and elitist nature, the AUB attracts students from across the entire country. Largely homogeneous in terms of socio-economic profiles, the university population presents a rather high level of diversity when it comes to sectarian and geographical origins (Author, 2013, p. 109). Likewise, studying at the AUB introduces students to its wider neighbourhood and, in particular, the district of Hamra. As mentioned in the previous section, this area retains particularities in terms of its location in West Beirut, its strong historical association with the pan-Arab leftist culture and its current dynamics of gentrification. Living on the campus is a de facto gate towards this specific social universe, susceptible to instigating change in young people's views. This is especially true for those who were not familiar with Hamra or West Beirut:

[My attachment to Beirut] helped me to compose my story and rationalise (...) my personal and political transformation [towards secularism]. I grew up in a place that is opposed to what I think Beirut really is [i.e., cosmopolitanism]. (...) I went to school in Jamhour, a French and Catholic institution, which represents the Lebanese Maronite identity. It is the symbol of Maronite elitism. I grew up there and then I went to the SaintJoseph University [another Jesuit and francophone institution]. But (...) meeting new people here, I realised my prejudices in favour of the French, European culture, against Arabism and all this. [Clara]

Clara's story highlights that her representation of alterity as a threat is not connected to a direct experience of violence but only to inherited prejudices. In such cases, entering a new territory is more likely to instigate change. Precisely because of its connections with its neighbourhood and the secularist milieus, the AUB provides an interesting standpoint to study such potential transformations. The narrative power of transitioning is even more explicit in Gloria's account. On 
the map of the campus, she circled one of the university gates, explaining that, two years ago, on her way to register at the AUB, a decisive argument with her ex-fiancé erupted on this precise spot. From the evocation of this intimate episode unfolds the tale of what she perceives as a struggle between the old and the new. For her, this incident has developed into the symbol of a turning point in her life and her way of living in the city. Following this line of thought, she explains that she has turned her back on her past routines, now pursuing her aspiration to discover the city. While the evocation of her past revolved around the conservative environment of her hometown of Jounieh, painted as an incarnation of Christian Maronite provincial life, she depicted her present perception of the city as bursting with youthful energy. She stressed her attachment to secular and cosmopolitan milieus as well as her willingness to emancipate herself from the taboos of Lebanese society, particularly regarding gender relations and sexuality. In her narrative reconstruction, her entrance through the university gate illuminated the sectarian and patriarchal structures in which she grew up and now intends to shake up by deliberately spending time in the Western part of the city and socialising in cafés and restaurants renowned for their cosmopolitan and liberal ambiance. However, her call for emancipation and gender equality bears limitations, exposing the complexity of intergenerational navigation and the in-between state of her position:

If it were just for me, I would not follow the rules of the Lebanese society, especially for girls, because you cannot make your own decisions. [For example], I would not get married. (...) At the same time, (...) I really want my parents to approve of me. (...) So it is conflicting. (...) Ten years ago, no one would have dared to discuss such things as having relations before marriage. Now, women ask why men can do things women are not allowed to do. [Gloria, master student, Jounieh]

Transitioning evokes the daily as well as existential turning points in the lives of the participants. The passage between spaces of negotiation and spaces of transition relates to a diachronic evolution from the moment of encounter with alterity to the time of engaging with it. Transitioning symbolises this time-space of vacillation, when it becomes possible to move from one space, one experience, to another. As such, it opens up the possibility for renewed modalities of interaction with the other. This potentiality of change becomes fully visible in the last chronotope. 


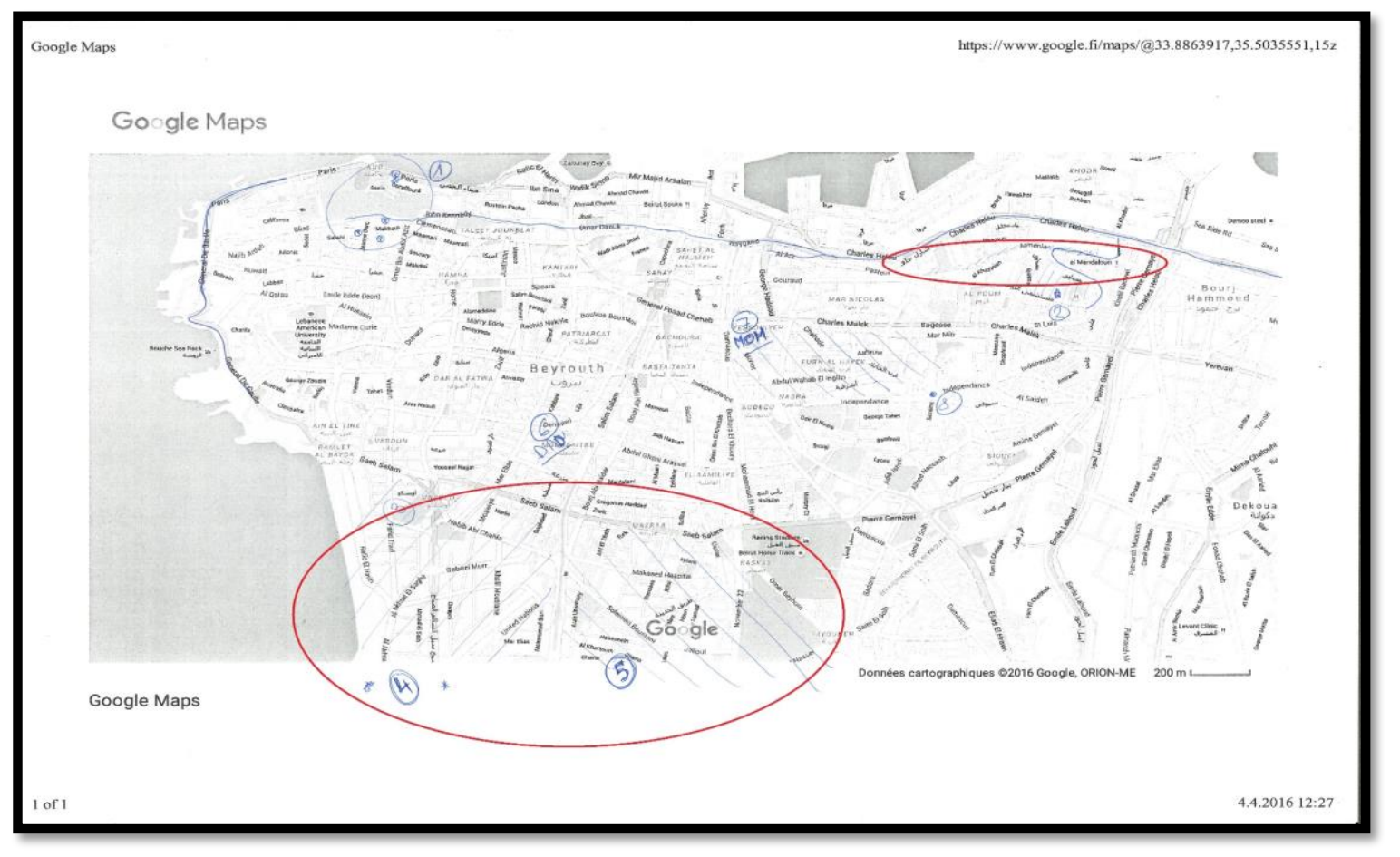

Figure 5. Explorations in Luna's collaborative map of Beirut.

One final mode of engaging with the city stands out from students' collaborative maps: the discovery of spaces that were, for them, emblematic of youth sociability - ranging from bars to nightclubs, and shopping malls to art galleries. Participants underline not only their importance in their everyday life but also their exploratory dimension. More precisely, it was their insistence on the circulation of youthful places and practices that hinted at the image of frontier spaces, a notion that encapsulates ideas of exploration, avant-garde and confrontation with boundaries. The experience of daily life in the AUB and, more generally, in Beirut, a plural city par excellence, stresses the questions of encounters, coexistence and engagement with alterity. For many of the young participants, new friendships and relationships often lead to a challenge of the social imagination of space inherited from primary socialisation. Luna, herself originating from the Maronite heartland of Keserwan, but whose new boyfriend lives in a suburb strongly associated with Shia Muslims and Hezbollah, explains:

The place I am living in [Keserwan] is the opposite of the area where my boyfriend lives. I am now talking in terms of religion or sect. (...) Now [that I visited the area], I am wondering if these two places are different just because I know they are different. And maybe they are not that different after all. (...) My image came from what people said that it was dense, crowded, unsafe. But what I have found out was different. It is dense and crowded, yes, but I didn't find it scary at all. Actually, I found it less scary than other areas like Achrafiyeh [the heart of Christian Beirut]. [Luna] 
While the portrayal of the two spaces as antagonists signals the lasting influence of sectarian imaginaries, the actual practices of space opens up the possibility of questioning these stereotypes. Concrete experiences transform territories that have long remained distant and fearsome into lived spaces, where the strength of imagination is confronted with the physical reality. Campus life, friendship and youth sociability together contribute to these experiences of discovery - i.e., renewed daily practices of coexistence, reminiscent of what Asef Bayat coins "everyday cosmopolitanism" (2010, p. 10). These practices challenge inherited representations and fears that partially lost their power with the return to peace. The appeal for youthful spaces is concretised through the development and rapid circulation of vibrant territories dedicated to arts, culture and nightlife. While such sites obviously exclude underprivileged or conservative youths, they evoke for the young people I met not only entertainment but also a desire for exploration, avant-gardism with the dose of gentrification that goes along it - and a redefinition of urban spaces emancipated from social control:

There is a circulation of hangout places. Before [in the early 2000s], it used to be in Monot Street, then in Gemmayzeh and Mar Mikhail [three Christian-populated neighbourhoods in East Beirut], and now in Badaro [a residential district], Qarantina and the River [both situated at the eastern limit of the municipality, next to the Armenian district of Burj Hammud]. They opened bars, art centres.... (...). It brings 'civil life' [i.e., non-sectarian] with it. [Liza, undergraduate student, West Beirut]

I love Gemmayzeh and Mar Mikhail because you can be there with your friends, or (...) with your lover, you can kiss or wear clothes that are not [appropriate]. In other neighbourhoods like Tareq al-Jadideh [a residential Sunni populated area known as conservative, often considered hostile to outsiders - all the more since Mona is Shia and does not wear the veil] (...), they have their own codes and you cannot do whatever you want. [Mona, master student, southern suburb]

Evocations of frontier spaces hint at an exploration of new, transforming territories in the city. Some aspects of this urban renovation relate to commercial and financial rationality. Flagship projects such as SOLIDERE, the reconstruction of Beirut souks (in fact, a luxurious shopping mall), or the creation of the opulent seaside complex of Zeituna Bay, all relate to predatory economic practices inaugurated after the wars when the rebuilding of downtown Beirut became a formidable business opportunity. As Mona Harb rightly points out, these neoliberal policies were the actualisation under another form of the processes of dispossession inaugurated during the wars when "militia leaders and their business partners seized most of Lebanon's coastline, building ports and touristic resorts illegally, extracting sand, and renting or buying public lands via shady deals" (Harb, 2017, §5). After the war, instead of being resurrected, these public spaces were handed over to private investors feeding on the real-estate fever (ibid.). Yet, in front of these dynamics of private capture of the urban space and exclusion of its inhabitants, Beirut's dwellers have expressed their 
desires to reclaim their city. The citizen campaigns to protect the port of Dalieh or to force the reopening of Horch Beirut, the biggest park in the Lebanese capital, provide telling examples. Similarly, among research participants, many mundane practices can be associated with such resistance efforts. Tareq, an undergraduate student in Architecture from West Beirut, details at length the ways he has gradually discovered Beirut's underground LGBT sites despite persistent ostracism. Officially prohibited by law, the existence of LGBT-friendly bars and nightclubs is made possible by a relative, circumstantial tolerance and, in some instances, the secretive support of influential figures. However, a rapid circulation of the venues is necessary to avoid attracting too much attention. His exploration convinced him to confront the prejudices of Lebanese society regarding homosexuality head on by courageously divulging his life choice to his Muslim family and friends, as well as through his engagement in the Lebanese LGBT movement Helem [Dream]. Discovering the city is calling for a reinvention of the relation to the other and renegotiation of the social norms.

Concerned with the dynamics encountered, positioning, transitioning and discovering highlight a process of complexification in the participants' experiences of urban territories and their understanding of the identities that populate them. While binary perceptions setting insiders against outsiders, and identity against alterity, remain vivid, they tend to become more complex as the young participants negotiate their position, move towards renewed conceptions and discover alternative spaces in the city. Such practices of exploration are only possible because their interpretations of spatial boundaries are transforming.

\section{CONFLICT TRANSFORMATION, PRIVATIZATION AND THE REINVENTION OF URBAN BOUNDARIES}

Wartime topographies and politico-religious territories still inform the narrations of lived space I collected. In particular, the imaginary of the Green Line remains pivotal in the projection of space. However, the ways the young people I met live out this centrality have altered. Almost 30 years after the end of the Lebanese wars, they take a somehow distant and reflective look on their own representations:

[Before] I did not know anything about West Beirut because there was this attitude that you stay where you live. (...) Now, I'm aware that my spaces are split between the East/West divide (...). They felt like separated areas not because I saw them like it but because I became aware of it through what people said. (...) I was unaware of it until I was accepted to the AUB. (...) All I knew was Badaro and my school. (...) It was a postwar reality. Mum was scared. We lived a confined life. (...) It's strange because we are a Muslim family and we were living in a Christian district. [Maya]

Maya's words illustrate the practical impact of the fresh memory of violence during her childhood, which translated into a life of confinement within restricted areas. She acknowledges that the 
East/West divide was given to her and mainly interpreted in terms of a sectarian framing. However, the very definition of the boundary as sectarian urges her to question the relevance of this interpretation, because her Muslim family was living in a predominantly Christian district. In fact, during the wars, a safe space was primarily a confined, local space of coexistence and mutual acquaintance where people could equally identify and be identified. In other words, acts of political and sectarian violence led to a separation primarily based on localism. In spite of their brutal efforts, militia organisations never achieved the construction of the homogenous sectarian territories they pursued (Picard, 2002, p. 150). For Maya, the reason behind this confinement remained vague until her studies at the AUB forced her to confront the memory of the separation and question its relevance. Similar reflections come back frequently in the data:

For us, separation was just a fact (...). My father used to work for Télé-Liban, in the West. So, we were not necessarily living a confined life, but [West Beirut] was something I did not know. For us, it was a practical difference, unlike my mother's family. They were engaged during the war [in the Christian Lebanese Forces militia] and had to leave Lebanon. When I see them, I am exposed to their stories and visions. They still live on war mythologies like Phoenicia and these kinds of very stupid things. [Clara]

This young woman, who admitted earlier in the interview that she had avoided crossing the former Green Line for years, argues that growing older and discovering new forms of sociability in and around the AUB pushed her to critically engage with "the prejudices [she] was taught, especially about the war". Unlike her exiled relatives, whose last memories of Beirut remain embedded in the reminiscence of the wars, she experienced the return to peaceful interaction with "the other". She describes their attitudes as if the temporality of violence had solidified in their imagination of the city. Using this contrasting example, she makes the claim of a generational change. For her, practices of spatial segregation, despite being perpetuated in the immediate postwar period, have been partly emptied of their meaning. In her words, as in those of many of the other participants, the experience of confinement within limited areas around the family house remains. However, it seems to work mainly at a practical level, as a reminiscence of everyday habits originally imposed by the conflict and subsequently routinised in the immediate postwar under the fresh souvenir of violence. Going to the AUB has pushed them to navigate the fears of their elders and has encouraged the composition of a renewed narrative of coexistence.

During and right after the war, East and West Beirut were divided. My parents used to think that the West was dangerous. (...) They were always scared of West Beirut. (...) Even now, when I come home late, I don't tell them that I was there. [Gloria]

[Sectarian geography] still affects us, in a way, but not as much as it used to. Because for us, the younger generation, it is not like for the older ones. The borders between areas are not that strong, especially for us who are born after the war. [Rami] 
My interlocutors concede that their imagination of the rest of the city was altered by the fact that they had to move beyond their former dwelling time-spaces, but they also claim that this changing attitude towards sectarian boundaries and alterity results from a generational gap, understood in the classical sense put forward by Mannheim - i.e., inspired by the alteration of experiences and historical contexts. While it partly describes the process of transformation after the violence halted in 1990, this generational claim must be primarily interpreted as performative. Asserting the distinction between generations allows them to delineate themselves as different from war and immediate postwar generations. In doing so, my interlocutors aspire to position themselves against the backdrop of the wartime legacy and demand that their agency is fully acknowledged. Their position constitutes the youth as "a social shifter" - i.e., they invoke their youth to construct, with the rest of society, specific "sets of social relationships that are dynamic and constructed in the invocation" (Durham, 2004, p. 589). The markings on our collaborative maps represent spaces, but they also represent claims about participants' agency in the city and what they perceive (or wish to perceive) as dynamics of change. It is not my intention to pretend that social and political boundaries are disaggregating. The memory of the Lebanese wars and the political and sectarian boundaries it conveys continue to inform their representation of territories in Beirut. Nonetheless, I believe that their claims have to be taken seriously because their practices and imaginations of space shed light on a genuine desire to relate to politico-religious boundaries differently. In contrast to their parents, whose vision of the city remained tied to direct experiences of violence, the students I met have lived spatial fragmentation as the result of daily routines. Having lost the unmediated experiences of intergroup violence, their understanding of societal divisions has altered. While not freed of prejudices and identity assignations (many ambiguities remain in their stories on this issue), the narratives they voiced include the possibility of a renovated experiment with alterity. Combined with the opportunities offered by their studies at the AUB, the slight inflection in their attitudes has created a gap with wartime stories and allowed them to explore alternative experiences of urban spaces. Following these paths has led many of them to uncover other boundaries beyond the political and sectarian divides. In particular, they have been confronted with the powerful forces that privatise the city. They explicitly experience this phenomenon of monopolisation as a dispossession, even though they mostly belong to the upper classes of the society. Deemed undesirable by a rationality of urban development based on luxurious tourism, they find themselves implicitly (through high-price policies) or explicitly (through barriers and gated areas like Zeituna Bay) excluded from their own city. Challenged by this alternative experience of assignation, they question what relevance the sectarian boundaries inherited from the war have today. Many of them even engage in mobilisations targeting the socio-political status quo, both within their university 
(e.g., the AUB Secular Club) and beyond (the social movement You Stink! of summer 2015, or the municipal platform Beirut Madinati - Beirut is my City).

Although they remember the confined practices of the city that prevailed during their childhood, these young people put forward how they have become gradually involved in appeased relationships with people and places they used to define as alterity. Their voices reveal that the significance of identification in urban encounters has also been supplemented (rather than replaced) by powerful dynamics of inclusion and segregation imposed by transnational socio-economic trends. As such, their words underline the ambivalence and ambiguities of this dialogue between Beirut's history of spatial differentiation and the forces shaping present-day practices of the city. This situation somehow echoes Zygmunt Bauman's insight that "contemporary cities are (...) the stages or battlegrounds on which global powers and stubbornly local meanings and identities meet, clash, struggle and seek a satisfactory, or just bearable, settlement" (Bauman, 2003, p. 21). We are not witnessing a decline in the politico-sectarian definition of the city in Lebanon. Yet, the stories collected throughout this project have nonetheless documented how categories of identity and alterity are partially reshuffled. Experiences of alternative boundaries such as gender and sexual identities, economic dispossession and generational change all contribute to these transformations. The ways these young people position themselves in relation to these issues shape how they understand their city and the social encounters it fosters.

\section{CONCLUSIONS}

The use of collaborative maps reveals how space incorporates many aspects of people's lives, from intimate, introspective thoughts to explicitly political designs. Identifying recurrent narrative constructions was an attempt to make connections between these various dimensions, and thus expose some of the social dynamics shaping experiences of the city in a postwar context. These stories have highlighted ways of practising and imagining Beirut that are not exclusively connected with wartime geographies. Such conclusions contrast with the dominant image of fixity of intergroup boundaries in postwar Lebanon. Of course, such an exercise is not without limitations. Undoubtedly, these stories are fragments rooted in what Mona Harb calls a "persistent urge to look for hopeful bits and pieces that persist in cities shattered by conflict and violence - shreds of enduring survival" (Harb, 2017, §3). Yet, the "situated knowledge" elaborated in this study underlines youthful attempts to navigate, negotiate and rediscover spatial settings in a complex environment still influenced by powerful politico-sectarian forces, but also shaped by global processes. The "particular truths" exposed here express the agency of the young people I met. They reveal the ways they are looking for and making sense of their encounters with and within their city. 
These interpretations, here used in the double meaning of allocation of signification and performance, are defined at the same time by their life trajectories (the opportunity to study at AUB and discover new areas of Beirut) and their perceived position as a postwar generation. Although anxious perceptions persist and sectarianism continues to be a governing power in Lebanon, equally so among the youth (e.g., Chamseddine, 2018), Lebanese postwar society is neither immobile nor monolithic. A detour by a micro, ethnographic approach enables us to shed light on gaps, particular situations in which frictions with the dominant forces are visible. These frictions have to be taken seriously. They call attention to the transformative power of micro-situations in postwar contexts. Ultimately, analysis of these micro-situations shows the necessity to reconsider the relation between the city and war beyond the dominant focus on destructive forces and anxious urbanism. Urban spaces, far from merely symbolising and reproducing conflicts, are also the place where mundane practices and imaginations reinvent the social fabric.

\section{REFERENCES}

List of interviews (anonymized), Beirut:

Gloria (Urban Design), 11.04.2016; Rami (Urban Design), 11.04.2016; Kamal (Sociology), 12.04.2016; Maya (Sociology), 12.04.2016; Clara (Sociology), 14.04.2016; Mona (Urban Design), 18.04.2016; Nisrine (Architecture), 20.04.2016 ; Luna (Architecture), 20.04.2016; Fadi (Architecture), 20.04.2016; Liza (Architecture), 21.04.2016; Nina (Architecture), 21.04.2016; Hoda (Architecture), 21.04.2016; Tareq (Architecture), 22.04.2016.

Bibliography:

Agnew, J. (2005). Sovereignty regimes: Territoriality and state authority in contemporary world politics. Annals of the Association of American Geographers, 95(2), 437-461.

Appadurai, Arjun. 1996. Modernity at large: Cultural dimensions of globalization. Minneapolis: University of Minnesota Press.

Author (2013). The full reference will be provided after the review process.

Bakhtin, Mikhail M. 1981. The dialogic imagination: Four essays. Austin: University of Texas Press.

Bakke, K.M., Linke, A.M., O’Loughlin, J., \& Toal, G. (2018). Dynamics of state building after war: External-internal relations in Eurasian de facto states. Political Geography, 63, 159-173.

Bauman, Zygmunt. 2003. City of fears, city of hopes. London: Goldsmith's College. 
Bayat, A. (2010). Life as politics. How ordinary people changed the Middle East. Cairo: American Univ. in Cairo Press.

Beck, U. (1999). World risk society. Cambridge: Polity Press.

Beydoun, A. (1993). Liban, itinéraires dans une guerre incivile. Paris: Karthala.

Brubaker, R. (2004). Ethnicity without groups. Cambridge: Harvard University Press.

Cerwonka, A. (2007). Nervous conditions: The stakes in interdisciplinary research. In A. Cerwonka \& L. Malkki. Improvising theory. Process and temporality in ethnographic fieldwork (pp.140). Chicago-London: The University of Chicago Press.

Chamseddine, A.F. (2018). Lebanon's up and coming. Synaps Network. Accessed date: 24.08.2018.

Coaffee, J. (2004). Recasting the 'ring of steel': Designing out terrorism in the city of London? In S. Graham (Ed.). Cities, war, and terrorism: Towards an urban geopolitics (pp.276-296). Malden: Blackwell.

Coward, M. (2004). Urbicide in Bosnia. In S. Graham (Ed.). Cities, war, and terrorism: Towards an urban geopolitics (pp.154-171). Malden: Blackwell.

Davie, M. (1998). L'université au Liban et les articulations à son environnement. In : Actes du Colloque «Cité et Université » (pp.118-128). Louaizeh : Notre-Dame University Press.

Davies, B., \& Harré R. (1990). Positioning: The discursive production of selves. Journal for the Theory of Social Behaviour 20(1), 43-63.

de Certeau, M. (1984). The practice of everyday life. Berkerley: University of California Press.

Durham, D. (2004). Disappearing youth: Youth as a social shifter in Botswana. American Ethnologist, 31(4), 589-605.

Deeb, L. (2006). An enchanted modern. Gender and public piety in Shi'i Lebanon. Princeton: Princeton University Press.

Endres, J. (2003). Profiting from war. Economic rationality and war in Lebanon. In D. Jung (Ed.). Shadow globalization, ethnic conflicts and new wars: A political economy of intra-state war (pp.119-139). London: Routledge.

Farish, M. (2004). Another anxious urbanism: Simulating defense and disaster in Cold war America. In S. Graham (Ed.). Cities, war, and terrorism (pp.93-109). Malden: Blackwell.

Fawaz, M., Harb, M., \& Gharbieh, A. (2012). Living Beirut's security zones: An investigation of the modalities and practice of urban security. City \& Society, 24(2), 173-195.

Fine, G.A., \& Fields, C.D. (2008). Culture and microsociology: The anthill and the veldt. The Annals of the American Academy of Political and Social Science, 619(1), 130-148. 
Fox, J., \& Jones, D. (2013) Migration, everyday life and the ethnicity bias. Ethnicities, 13(4), 385400.

Fregonese, S., \& Ramadan, A. (2015). Hotel geopolitics: A research agenda. Geopolitics, 20(4), 793-813.

Fuccaro, N. (2016). Violence and the city in the modern Middle East. Palo Alto: Stanford University Press.

Gadamer, H. (1999). Truth and method (2nd Ed.). New York: Continuum.

Garfinkel, H. (1967). Studies in ethnomethodology. Englewood Cliffs: Prentice-Hall.

Graham, S. (2010). Cities under siege. The new Military urbanism. London: Verso.

(2004). Introduction: Cities, warfare, and states of emergency. In S. Graham (Ed.). Cities, war, and terrorism: Towards an urban geopolitics (pp.1-25). Malden: Blackwell.

Hall, S. (1990). Cultural identity and diaspora. In J. Rutherford (Ed.). Identity: Community, culture, difference (pp.222-237). London: Lawrence \&Wishart.

Hanf, T. (2015). Coexistence in wartime Lebanon: Decline of a state and rise of a nation. London: I.B. Tauris.

Harb, M. (2017). Diversifying urban studies' perspectives on the city at war. International Journal of Urban and Regional Research (The City and war: Reflections on Beirut, Brussels and beyond). http://www.ijurr.org/spotlight-on-overview/the-city-at-war/harb/, Accessed date: 06.11.2018.

(2010). Le Hezbollah à Beyrouth (1985 - 2005): De la banlieue à la ville. Paris: Karthala.

Haraway, D. (1991). Situated knowledges: The science question in feminism and the privilege of partial perspective. In Simians, cyborgs, and women: the reinvention of nature (pp.183-201). New York: Routledge.

Haugbolle, S. (2010). War and memory in Lebanon. Cambridge: Cambridge University Press.

Humphreys, D. (2015). The reconstruction of the Beirut central district: An urban geography of war and peace. Spaces and Flows: An International Journal of Urban and Extra-Urban Studies, 6(4), 1-14.

Kaufman, S.J. (2001). Modern hatred: The symbolic politics of ethnic War. Ithaca: Cornell University Press.

Lassiter, L.E. (2005). The Chicago guide to collaborative ethnography. Chicago: University of Chicago Press.

Leach, E. (1967). An anthropologist's reflections on social survey. In G. Jongmans \& P.C.W. Gutkind (Eds.). Anthropologists in the field (pp.75-88). Assen: Van Gorcum. 
Lederach, J.P. (1995). Preparing for peace: Conflict transformation across cultures. Syracuse: Syracuse University Press.

Leenders, R. (2012). Spoils of truce: Corruption and state building in postwar Lebanon. Ithaca: Cornell University Press.

Lefebvre, H. (1991). The production of space. Oxford: Basil Blackwell.

Makdisi, U. (2000). The culture of sectarianism. Berkeley-Los Angeles-London: University of California Press.

Malkki, L. (2007). Tradition and improvisation in ethnographic fieldwork. In A. Cerwonka \& L. Malkki. Improvising theory. Process and temporality in ethnographic fieldwork (pp.162-187). Chicago-London: The University of Chicago Press.

McCahill, M. (2002). The surveillance web: The rise of visual surveillance in an English city. Cullompton: Willan Publishing.

McFarlane, C. \& Anjaria, J.S. (2013). Introduction: Conceptualising the city in South Asia. In C. McFarlane \& J.S. Anjaria (Eds.). Urban navigations: Politics, space and the city in South Asia (pp.1-20). London: Routledge.

Mermier, F., \& Mervin S. (2012). Introduction. Une approche anthropologique du leadership au Liban. In F. Mermier \& S. Mervin (Eds.). Leaders et partisans au Liban (pp.7-32). ParisBeirut: Karthala-IFPO-IISMM.

Mermier, F., \&Picard, E. (2007). Introduction. In F. Mermier \& E. Picard (Eds.). Liban, une guerre de trente-trois jours (pp.5-13). Paris: La Découverte.

Miall, H. (2004). Conflict transformation: A multi-dimensional task. In A. Austin, M. Fisher, \& N. Ropers (Eds.). Transforming ethnopolitical conflicts (pp.67-90). Wiesbaden: Verlag für Sozialwissenschaften.

Picard, E. (2002). Lebanon, a shattered country: Myths and realities of the wars in Lebanon. New York: Holmes \&Meier.

Ricoeur, P. (1990). Soi-même comme un autre. Paris: Seuil.

(1973). Ethics and Culture-Habermas and Gadamer in Dialogue. Philosophy Today, 17, $153-65$.

Risse, T. (Ed.). (2011). Government with a state? Policies and politics in areas of limited statehood. New York: Columbia University Press.

Ristic, M. (2014). 'Sniper Alley': The politics of urban violence in the besieged Sarajevo. Built Environment, 40(3), 342-356.

Sharkey, P., \& Faber, J. (2014). Where, when, why, and for whom do residential contexts matter? Moving away from the dichotomous understanding of neighborhood effects. Annual Review of Sociology, 40, 559-579. 
Spiller, R.J. (2000). Sharp corners: Urban operations at century's end. Fort Leavenworth: Combat Studies Institute, US Army Command and General Staff College Press.

$\mathrm{Su}, \mathrm{X}$. (2018). Fragmented sovereignty and the geopolitics of illicit drugs in northern Burma. Political Geography, 63, 20-30.

Traboulsi, F. (2007). A history of modern Lebanon. London: Pluto Press.

Volk, L. (2010). Memorials and martyrs in modern Lebanon. Bloomington: Indiana University Press.

Warchitecture (1993). Urbicide - Sarajevo=Sarajevo, Une Ville Blessée.

Williams, R.J. (2004). The anxious city: British urbanism in the late 20th Century. London: Routledge. 